\title{
PREDICTION OF LACTATION CURVE PATTERN FOR DAILY MILK, FAT, AND PROTEIN YIELDS IN EGYPTIAN BUFFALO
}

\author{
Manal M. El-Bramony ${ }^{1}$, H.A. El-Regalaty ${ }^{1}$, A. A. Ashmawy ${ }^{2}$ and Kawthar A. Mourad ${ }^{1}$ \\ 1- Animal Production Research Institute, Ministry of Agriculture and Land Reclamation, Dokki, Giza, Egypt, 2- \\ Department of Animal Production, Faculty of Agriculture, University of Ain Shams, Cairo, Egypt
}

\section{SUMMARY}

Data were collected at monthly intervals over the period from February 2013 to March 2015 to select the best equation to describe the lactation curve pattern for the daily milk traits. A total of 2265 test day records of milk yield (MY), fat yield (FY) and protein yield (PY) in the first seven lactations for 263 Egyptian buffalo cows raised at three experimental herds belonging to the Animal Production Research Institute, Egypt were analyzed. Four non linear equations were compared to predict daily milk yield traits, Wood's (WOD), Wilmink's (WIL), Guo and Swalve (GS) and Cobby and Le Du (CLD). For all models, the initial and ascending to peak daily yield phases were contributed with high variability of lactation curve pattern. In a comparison with the WIL, the three equations (WOD, CLD and GS, respectively) had the low values with Residual Standard Deviation (RSD), Akaike Information Criterion (AIC) and Schwarz Bayesian Criterion (SBC) criteria over the first seven lactations. Based on RSD, AIC and SBC criteria, Wood's equation showed more flexibility than other models to explore lactation curve pattern for expected daily milk yield traits. Considering values obtained by the WOD model, the expected daily yield at peak, time at peak daily yield and persistency ranged from 4.59 to $7.38 \mathrm{~kg}$, 5.03 to $8.23 \mathrm{wk}$ and 40.26 to $65.90 \%$, respectively for MY. The corresponding values varied between 0.395 and $0.467 \mathrm{~kg}, 5.39$ and $9.35 \mathrm{wk}$ and 41.53 and $72.00 \%$, respectively for $F Y$ and varied between 0.230 and $0.263 \mathrm{~kg}$, 4.05 and $8.13 w k, 40.33$ and $70.41 \%$, respectively for PY. Moreover, higher persistency was observed for MY, FY and PY in the $1^{\text {st }}$ lactation (65.90, 72.00 and 70.41\%, respectively), which declined till the fifth lactation and then tended to be almost constant till the seventh one (47.60, 48.76 and 47.32\%, respectively).

Keywords: Buffalo cows, lactation curve, daily milk yield traits, non linear equations and persistency

\section{NTRODUCTION}

The nonlinear models are widely used in dairy cattle to describe a relatively wide range of lactation curve shapes (Cobby and Le Du, 1978). The graphical representation of daily milk yield against time after calving is defined a lactation curve (Olds et $a l .$, 1979). Lactation curve can be characterized by coefficients of mathematical functions to predict the trend at different stages of lactation. Primarily, a rapid increase from calving to attain a peak period in a few weeks, and a gradual decline until milking is no longer practical determines the shape of the lactation curve (Olds et al., 1979). In dairy cattle, information of pattern of the lactation curve along trajectory could assist in determining biological and economical efficiency for purposes of feeding and selection (Grossman and Koops, 1988).In addition, costs of prolonged calving interval have been demonstrated to greatly depend on milk yield in the latter part of lactation (Dijkhuizen et al., 1985).

The use of test day records (TD) would permit better removing of more sources of variation through more precise modeling of individual TD yields as compared with traditional models; avoid the use of extension factors, providing longitudinal information and offer more flexible system of evaluation. It allows evaluation based on a limited number of TD records during lactation (Ptak and Schaeffer, 1993 and Swalve, 1995).Information of lactation curve pattern of buffalo cows at different stages of lactation for milk yield traits based on test-day records using mathematical equations is very limited. Therefore, the objective of the study was to select the best equation to describe the lactation curve for the daily milk yield traits.

\section{MATERIALS AND METHODS}

\section{Description of the data set:}

Data were collected at monthly intervals over the period from February, 2013 to March, 2015 from three buffalo experimental herds belonging to the Animal Production Research Institute (APRI), Ministry of Agriculture, and Land Reclamation. A total of 2265 test day records of daily milk yield traits (milk, fat, and protein) for 263 buffalo cows, in the first seven lactations were used.

Test day (TD) records from the first seven lactations between 5 and 305 days in milk (DIM) classes were considered in the statistical analysis. In addition, the first class included test days between 5 and 15 DIM and all the subsequent tests were of $30 \mathrm{~d}$ interval up to 305 DIM. Buffalo cows those had less than 4TD records/lactation were excluded. DIM data after 305 days was discarded as well from data file. Data were classified according to days in milk into eleven classes.

Fat and protein percentages were measured by the automated method of infrared absorption 
spectrophotometry (Milk-o-Scan); at the Dairy Services Unit, APRI, Sakha, Kafr El-Sheikh Governorate. Milking was practiced twice a day at 7:00 am and 4:00 pm throughout the lactation. Morning and evening milk yields were recorded and composite samples of the two milking were taken to determine fat and protein percentages. Fat and protein yields per lactation were calculated by the product of fat and protein percentages and daily milk yield. Milk yield traits studied were milk yield (MY, $\mathrm{kg} / \mathrm{d}$ ), fat yield (FY, $\mathrm{kg} / \mathrm{d}$ ) and (PY, $\mathrm{kg} / \mathrm{d}$ ) of the first seven lactations.

\section{Mathematical models:}

Daily milk yield traits were analyzed with nonlinear models by Gauss Newton iteration method using PROC NLIN (SAS, 2002) to estimate lactation curve parameters.

The following mathematical functions were applied: Wood (1967) model (WOD);

$$
\mathrm{Y}_{\mathrm{t}}=\mathrm{at}{ }^{\mathrm{b}} \exp (-\mathrm{ct})
$$

Wilmink, (1987) model (WIL);

$$
\mathrm{Y}_{\mathrm{t}}=\mathrm{a}+\mathrm{b} \exp (-\mathrm{kt})+\mathrm{ct} \quad\{2\}
$$

Guo and Swalve (1995) model (GS);

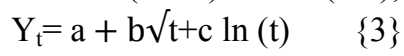

Cobby and Le Du, (1978) model (CLD);

$$
\mathrm{Y}_{\mathrm{t}}=\mathrm{a}-\mathrm{bt}-\mathrm{a} \exp (-\mathrm{ct}) \quad\{4\}
$$

Where: $Y_{t}$ is the average daily milk yield traits measured at the test day $t(1,2, \ldots, 11) ; " a "$ is the initial yield just after calving; " $b$ " is the ascending slope parameter up to peak yield, and "c" is the descending slope parameter after peak yield, and "exp" is the constant refers to the natural exponential function. According to the suggestion of Wilmink (1987) parameter $\mathrm{k}$ is related to the moment of peak, which is about $50 \mathrm{~d}$ and usually assumes a fixed value, derived from a preliminary analysis made on average production (Vargas et al., 2000). In a preliminary analysis, $\mathrm{k}$ was estimated at 0.147 .

The variables related to shape of lactation curve according to Wood (1967) model were time at peak yield (TPY,wk), peak yield (PY, kg) and persistency $(\mathrm{P}, \%)$ values for this model calculated as $\mathrm{TPY}=\mathrm{b} / \mathrm{c}$, $\mathrm{PY}=\mathrm{a}(\mathrm{b} / \mathrm{c})^{\mathrm{b}} \exp ^{(-\mathrm{b})}$ and $\mathrm{P}=-(\mathrm{b}+1) \ln (\mathrm{c})$. Fixed effects of herd, test date, and days in milk classes affecting on lactation parameters were included in the statistical analysis.

\section{Criteria for all models:}

Goodness of fit models was evaluated according to following criteria:

a) Residual Standard Deviation (RSD, Neter et al., 1985).

$$
\mathrm{RSD}=\sqrt{ } \mathrm{RSS} / \sqrt{ }(\mathrm{n}-\mathrm{p}) ;
$$

Where: RSS is the residual sum of squares, $n$ is the number of observations and $p$ is the number of parameters in the model.

b) Akaike Information Criterion (AIC, Akaike, 1974).

$\operatorname{AIC}(\theta)=(-2) \log (\mathrm{L})+2(\mathrm{~K})$; c) Schwarz Bayesian Criterion (SBC, Schwarz, 1978).

$\operatorname{SBC}(\theta)=(-2) \log (\mathrm{L})+\mathrm{K} \ln (\mathrm{N})$;

Where: L: is the maximum likelihood, $\mathrm{k}$ : is the number of independent parameters and $\mathrm{N}$ : is the sample size.

AIC and SBC are used to impose a penalty according to the number of parameters estimated. The SBC is more severe than one imposed by AIC (Littell et al., 1998). When the maximum likelihood estimates of the parameters give the minimum of AIC and SBC, the expected equation is considered a good one.

\section{RESULTS AND DISCUSSION}

\section{Actual and predicted lactation curve pattern:}

For all lactations, the pattern of actual and predicted daily yield traits (milk, fat, and protein) is graphically represented in Figures (1 to 7).

In the first lactation, average daily yield traits started at lower level of production at first DIM class. It reached the maximum daily yield in a shorter time at second DIM class, followed by daily gradual decline until the end of lactation at eleventh DIM class for actual, WOD, GS, and CLD functions, whereas the WIL function had over estimates daily yields in first DIM class, followed by a gradual decrease until to the end of lactation (Figure 1).

Figures (from 2 to 4 ) represented the actual and predicted lactation curve pattern for yields from the second to fourth lactations. The results showed that the actual, WOD and CLD equations had similar lactation curve pattern. Daily yields increased till the $3^{\text {rd }}$ DIM class and then the curves decreased to the $9^{\text {th }}$ DIM class and then sharply decreased in the $11^{\text {th }}$ one (Figure 2). The WIL and GS functions had different trend. Daily yields increased reaching maximum level at the $2^{\text {nd }}$ DIM class (Figure 2). Then the curves decreased up to the $9^{\text {th }}$ DIM class and then sharply decreased in the $11^{\text {th }}$ one.

As for $2^{\text {nd }}, 3^{\text {rd }}$ and $4^{\text {th }}$ lactations had similar pattern of actual and WOD equation while, it had different trend of WIL, GS, and CLD equations (Figures 3 and 4).

The actual and predicted pattern of daily yields is presented in Figures (5 to 7) in the rest lactations. Daily yields increased till the second DIM class and then decreased gradual to the end of lactation stage at eleventh DIM class. 


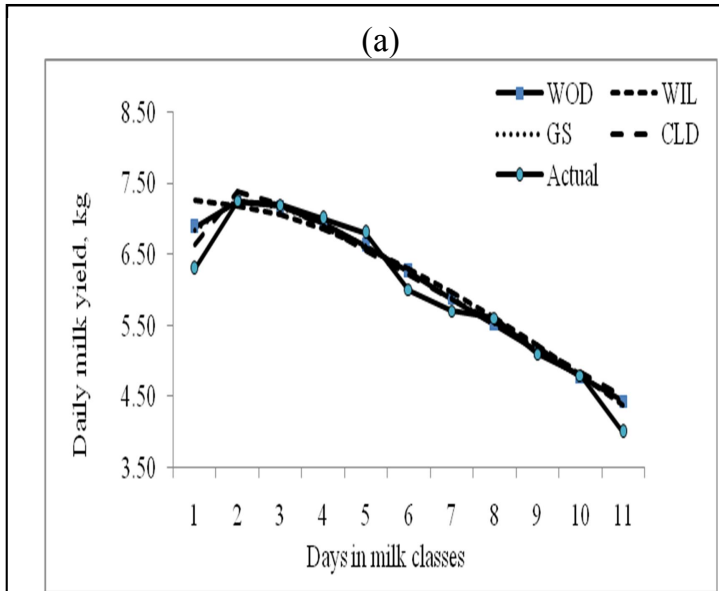

(b)

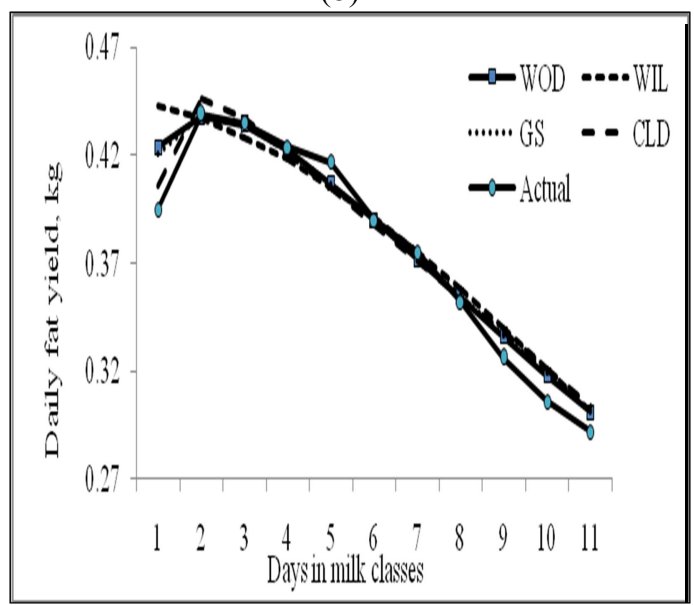

(c)

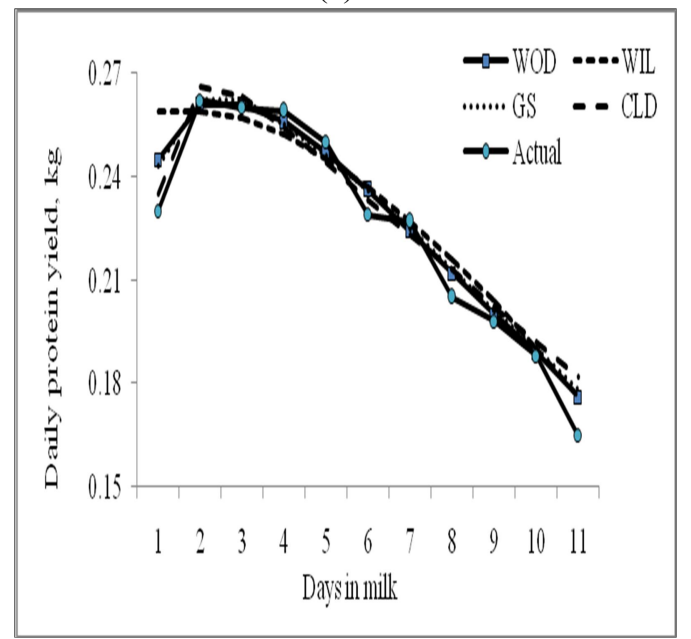

Fig. 1. Actual and predicted curves sorted by daily yield traits: (a): milk ; $(\mathrm{b})$ : fat and (c): protein of the $1^{\text {st }}$ lactation. The first class included test days between 5 and 15 DIM class and all the subsequent tests were of $30 \mathrm{~d}$ interval up to 305 DIM. Number of records for this lactation: 274 test day records.

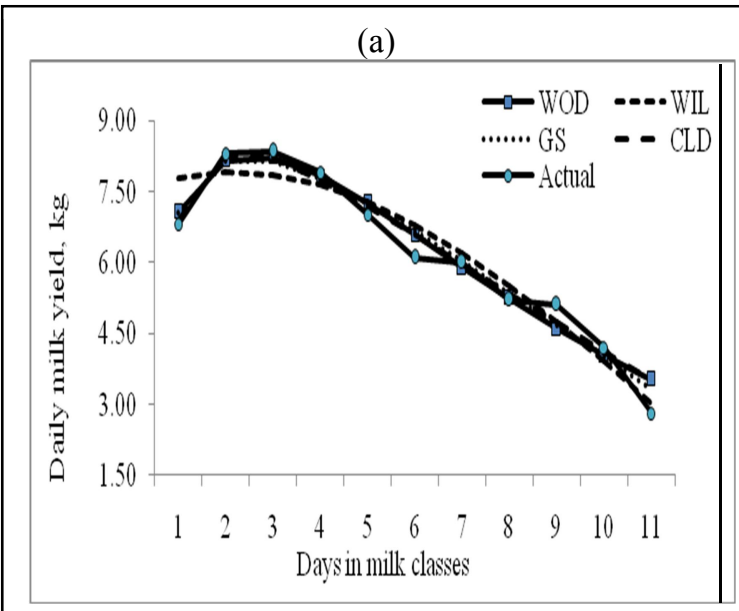

(b)

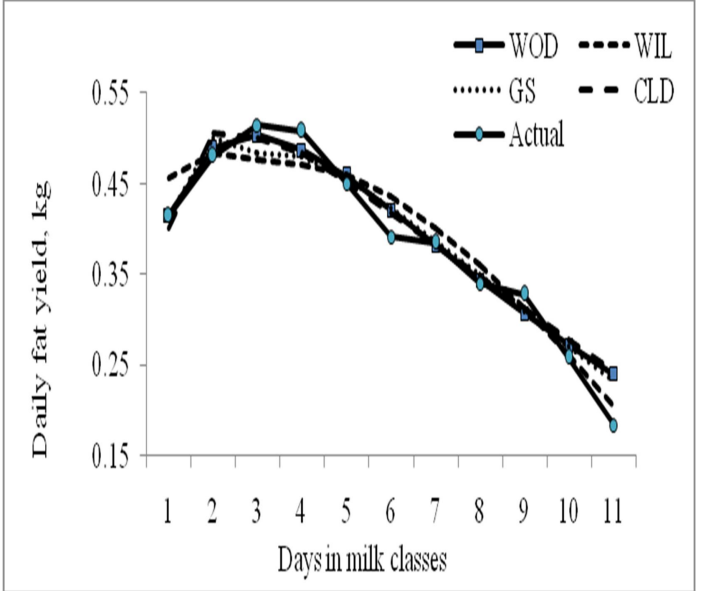

(c)

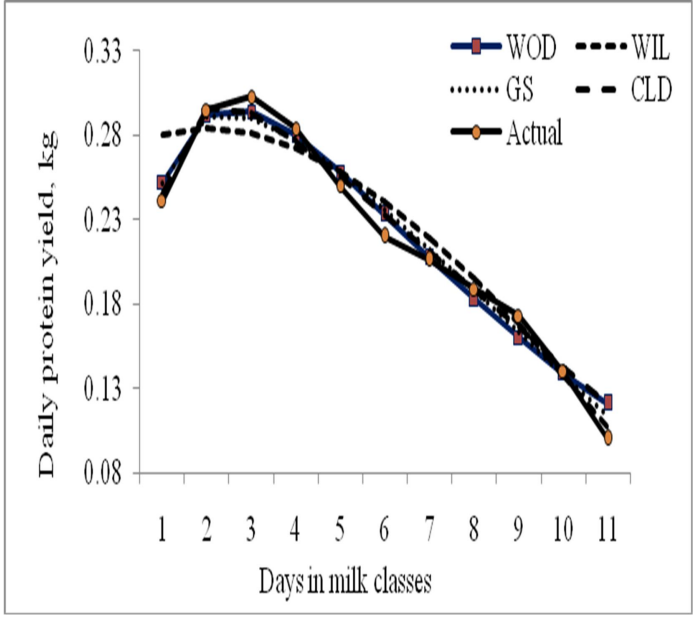

Fig. 2. Actual and predicted curves sorted by daily yield traits: (a): milk; (b): fat and (c): protein of the $2^{\text {nd }}$ lactation. The first class included test days between 5 and 15 DIM class and all the subsequent tests were of 30d interval up to 305 DIM. Number of records for this lactation: 320 test day records. 


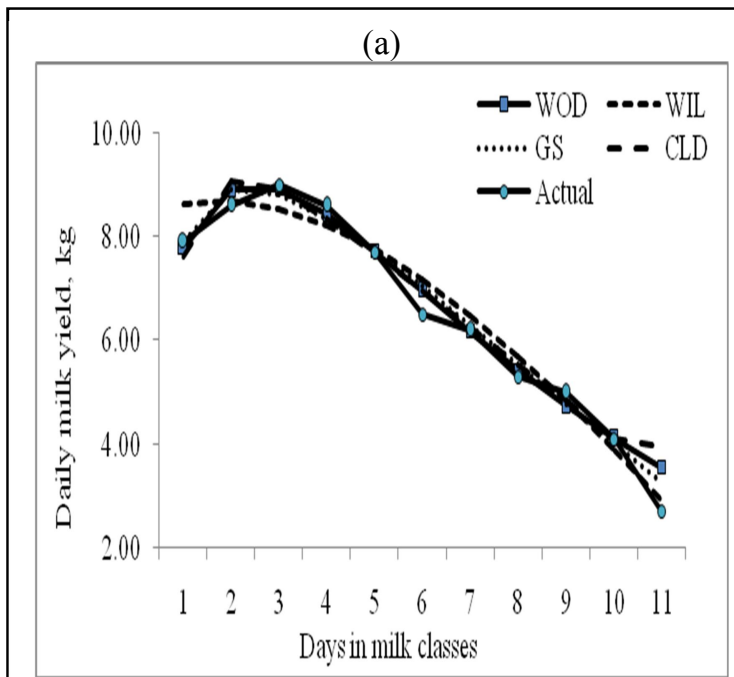

(b)

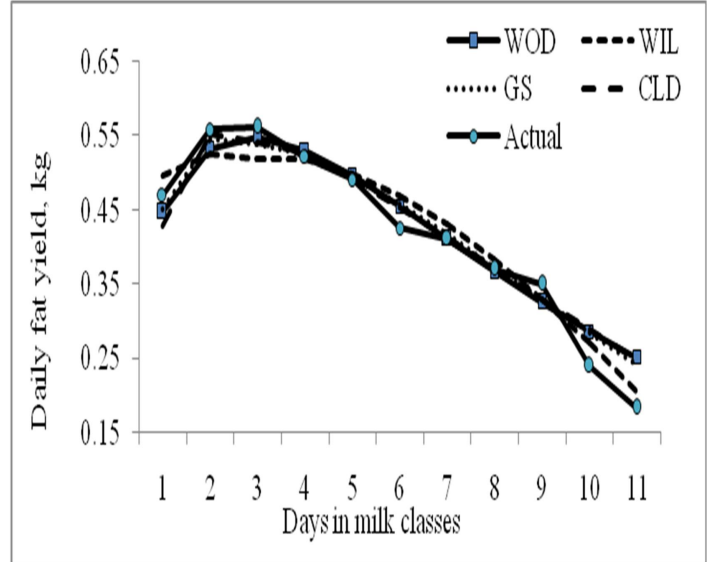

(c)

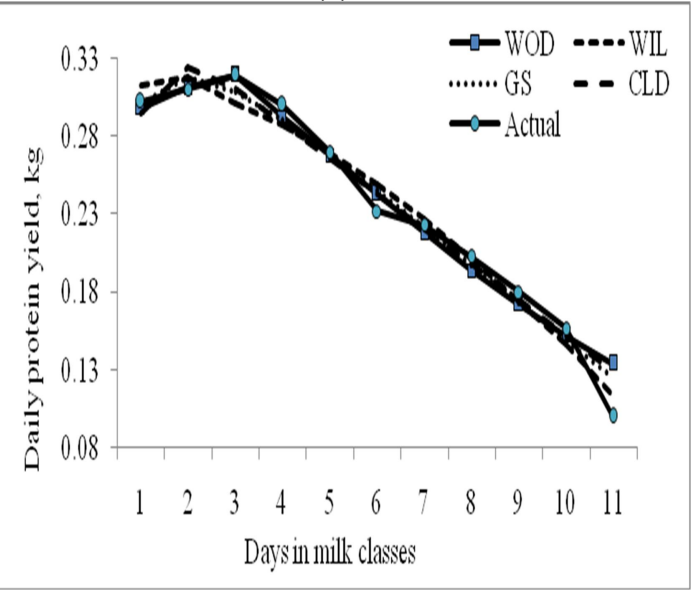

Fig. 3. Actual and predicted curves sorted by daily yield traits: (a): milk; (b): fat and (c): protein of the $3^{\text {rd }}$ lactation. The first class included test days between 5 and 15 DIM class and all the subsequent tests were of 30 -d interval up to 305 DIM. Number of records for this lactation: 387 test day records.

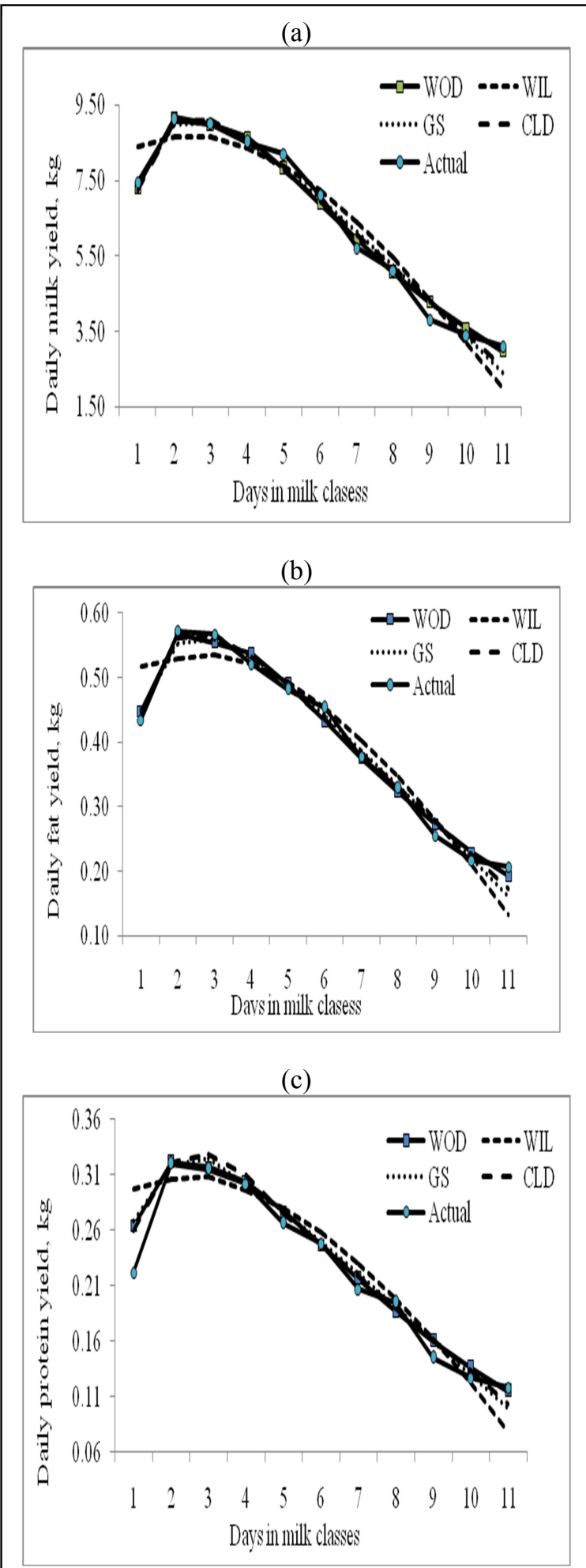

Fig. 4. Actual and predicted curves sorted by daily yield traits: (a): milk; (b): fat and (c): protein of the $4^{\text {th }}$ lactation. The first class included test days between 5 and 15 DIM class and all the subsequent tests were of 30-d interval up to 305 DIM. Number of records for this lactation: 371 test day records 


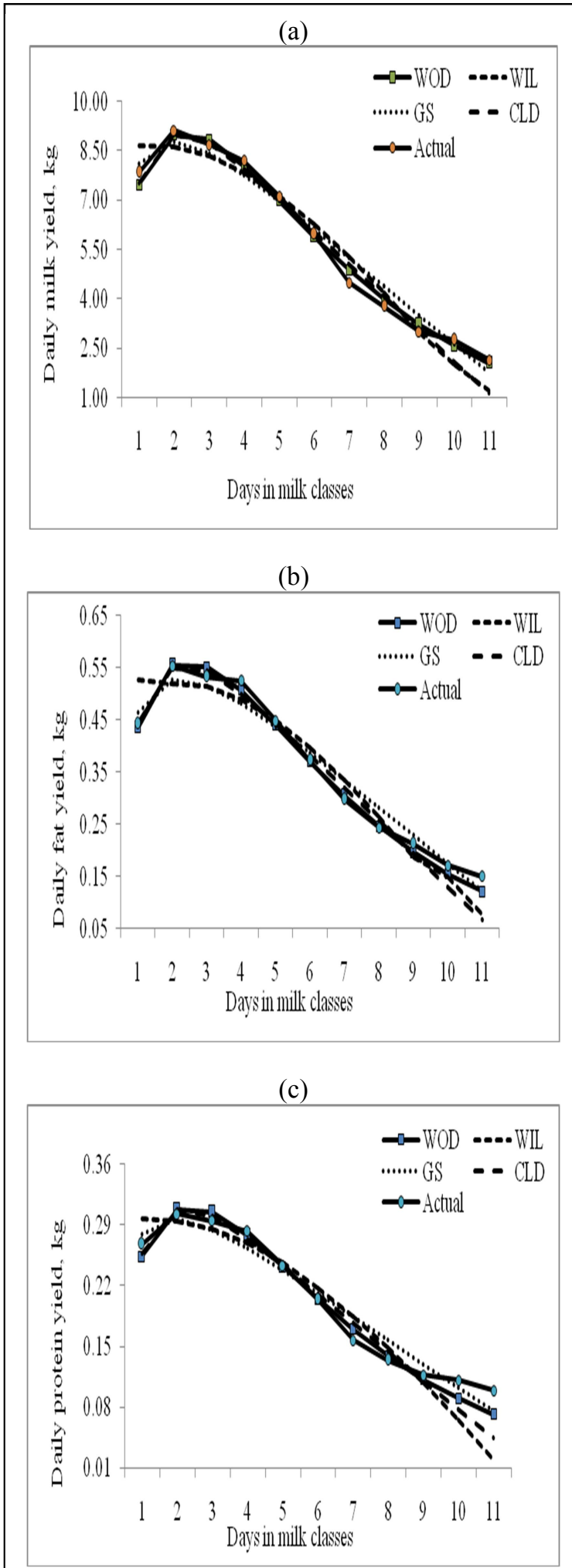

Fig. 5. Actual and predicted curves sorted by daily yield traits: (a): milk; (b): fat and (c): protein of the $5^{\text {th }}$ lactation. The first class included test days between 5 and 15 DIM class and all the subsequent tests were of 30-d interval up to 305 DIM. Number of records for this lactation: 370 test day records

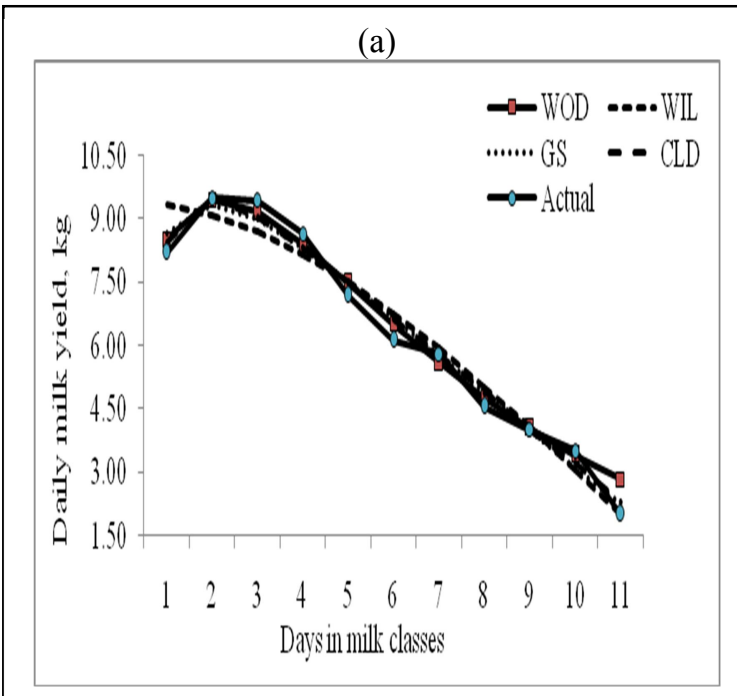

(b)

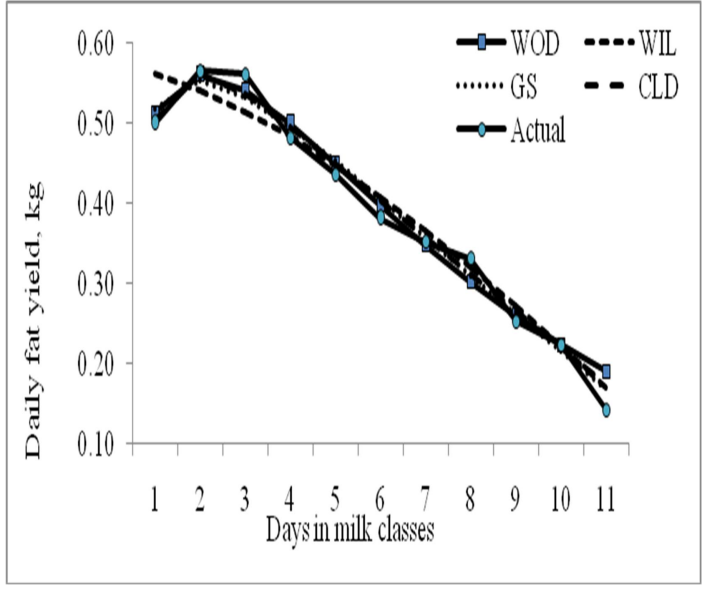

(c)

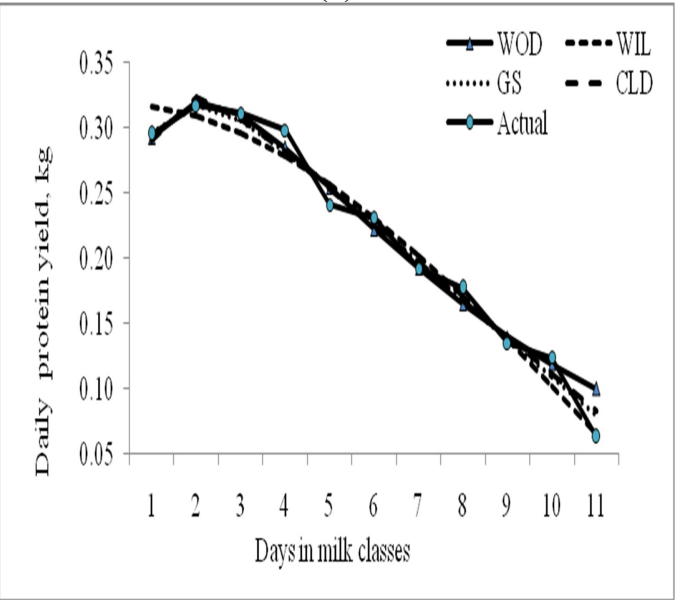

Fig. 6. Actual and predicted curves sorted by daily yield traits: (a): milk; (b): fat and (c): protein of the $6^{\text {th }}$ lactation. The first class included test days between 5 and 15 DIM class and all the subsequent tests were of 30 -d interval up to 305 DIM. Number of records for this lactation: 298 test day records. 


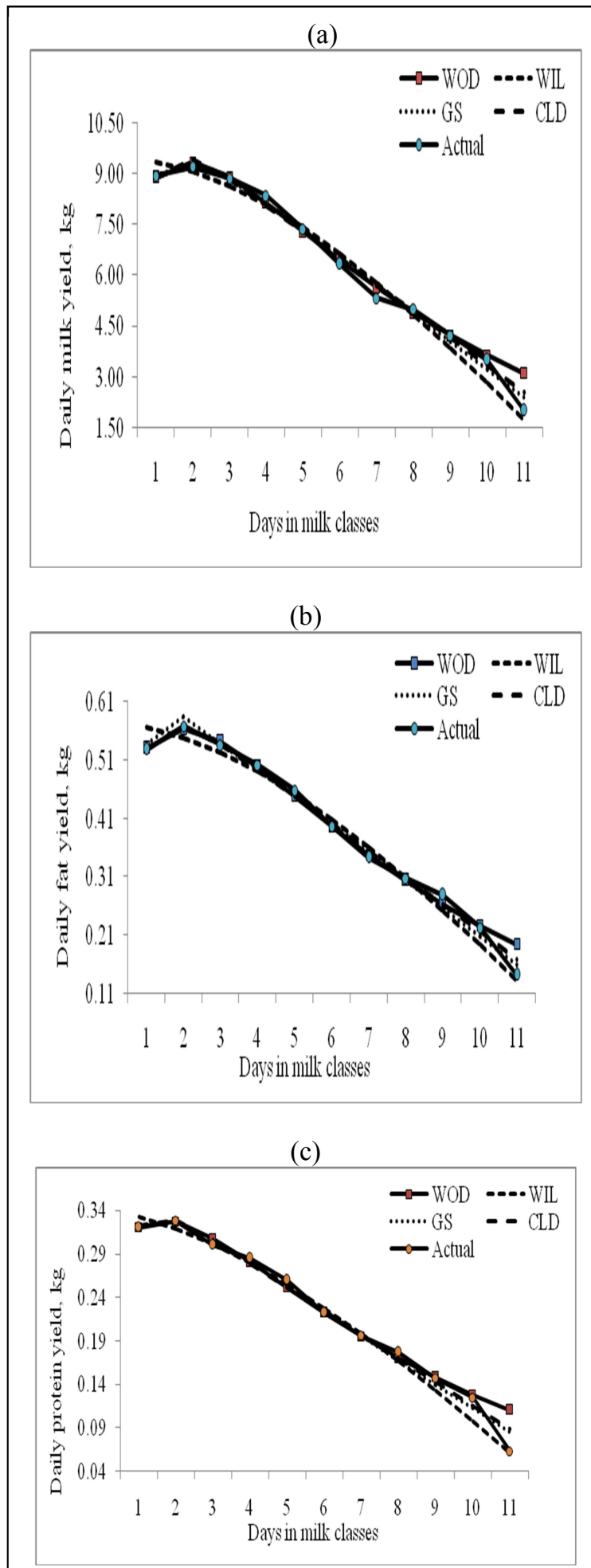

Fig. 7. Actual and predicted curves sorted by daily yield traits: (a): milk; (b): fat and (c): protein of the $7^{\text {th }}$ lactation. The first class included test days between 5 and 15 DIM class and all the subsequent tests were of 30-d interval up to 305 DIM. Number of records for this lactation: 245 test day records.
In conclusion, actual daily yield traits peaked at approximately third DIM class in the $2^{\text {nd }}$ and the $3^{\text {rd }}$ lactations while, other rest lactations had maximum yields at the $2^{\text {nd }}$ DIM class. On the other hand, the average of daily yield traits gradually increased with advanced lactation number from the $1^{\text {st }}$ to $3^{\text {rd }}$ lactations followed by a slight decrease till the $4^{\text {th }}$ lactation and then increased until the $7^{\text {th }}$ one (Figures 1 to 7). The pattern of change in lactation curves for yield traits were depressed in the $5^{\text {th }}$ up to the $7^{\text {th }}$ DIM classes. However, Stanton et al. (1992) suggested that increasing influence of pregnancy might provide a partial explanation, to this depression.

The pattern of change in the actual and predicted lactation curves for daily yield traits over days in milk classes observed in this study was in agreement with those reported by Samak et al. (1988); Mansour et al. (1993), Badran et al. (2002); El-Bramony et al. (2004); Aziz et al. (2006) and El-Bramony (2011) in Egyptian buffalo and Kumar and Bhat (1979); Catillo et al. (2002); Cerón-Muñoz et al. (2002) and Tonhati et al. (2008) for other populations of buffalo.

In general, predicated lactation curves provided satisfactory fit for yield traits up to the $9^{\text {th }}$ DIM class. Then all models showed inability to fit the rest of lactation curves till the end of lactation (Figures 1 to 7). In earlier study Grossman and Koops (1988) reported that a systematic deviation from actual milk yield is observed especially at the beginning and at the end of long (more than 305 days) lactations. Moreover, Cobby and Le Due (1978) and Olori et al. (1999) reported that the bias in predicting daily milk yield with non-linear models depends on the stage of lactation.

The general pattern of the lactation curve for daily yields in the $1^{\text {st }}$ and $7^{\text {th }}$ lactations differ from the $2^{\text {nd }}$ to $6^{\text {th }}$ one. It was sharply convex in the $1^{\text {st }}$ and $7^{\text {th }}$ lactation when compared with those from $2^{\text {nd }}$ to $6^{\text {th }}$ lactation, which seems sighlty concave.

\section{Lactation curve parameters:}

Regression parameter estimated and criteria of yield traits for different equations over 7 lactations are in Tables ( 1 to 3 ). Lactation curve parameters characterized by the initial yield "a" just after calving, the ascending slope parameter up to the peak yield " $b$ " and the descending after peak yield " $c$ " of each equation for yield traits. All estimated regression coefficients were significant $(P<0.05)$ of all lactations for milk yield traits.

In comparison among models, WOD model had lower average initial daily yields "a" after calving in first lactation and then tend to slightly increase as lactation order advanced (Tables 1 to 3).This trend was in accordance with Mansour et al. (1993), Aziz et al. (2006) and Abdel-Salam et al. (2011) for Egyptian buffalo and Silvestre et al. (2009) and Jingar et al. (2014) for dairy cows. 
Egyptian J. Anim. Prod. (2016)

Table 1. Estimated regression parameters and their standard errors and criteria of expected curves for daily milk yield

\begin{tabular}{|c|c|c|c|c|c|c|c|}
\hline \multirow{2}{*}{\multicolumn{2}{|c|}{$\begin{array}{l}\text { Lactation } \\
\text { number / } \\
\text { model }^{1}\end{array}$}} & \multicolumn{3}{|c|}{ Regression parameter estimates $^{2}$} & \multicolumn{3}{|c|}{ Criteria $^{3}$} \\
\hline & & $\mathbf{a} \pm \mathbf{S E}$ & $\mathbf{b} \pm \mathbf{S E}$ & $\mathbf{c} \pm \mathbf{S E}$ & RSD & AIC & SBC \\
\hline \multicolumn{8}{|c|}{$1^{\text {st }}$} \\
\hline & WOD & $7.558 \pm 0.428$ & $0.211 \pm 0.114$ & $0.094 \pm 0.028$ & 2.7318 & 7.5777 & 7.8207 \\
\hline & WIL & $11.310 \pm .3 .969$ & $-4.035 \pm 3.975$ & $-0.558 \pm 0.274$ & 2.7452 & 7.6372 & 7.8815 \\
\hline & GS & $11.220 \pm 1.067$ & $-4.338 \pm 1.357$ & $3.234 \pm 1.347$ & 2.7377 & 7.5957 & 7.8386 \\
\hline & CLD & $8.269 \pm 0.400$ & $0.341 \pm 0.065$ & $1.858 \pm 0.503$ & 2.7346 & 7.5789 & 7.8213 \\
\hline & WOD & $8.469 \pm 0.465$ & $0.471 \pm 0.123$ & $0.182 \pm 0.034$ & 2.8309 & 8.1437 & 8.4372 \\
\hline & WIL & $19.278 \pm 3.796$ & $-11.874 \pm 4.391$ & $-1.266 \pm 0.313$ & 2.8621 & 8.3209 & 8.6201 \\
\hline & GS & $15.576 \pm 1.244$ & $-8.521 \pm 1.531$ & $6.669 \pm 1.453$ & 2.8368 & 8.1739 & 8.4679 \\
\hline & CLD & $10.267 \pm 0.569$ & $0.615 \pm 0.090$ & $1.310 \pm 0.244$ & 2.8325 & 8.1495 & 8.4445 \\
\hline \multicolumn{8}{|c|}{$3 \mathrm{rd}$} \\
\hline & WOD & $9.427 \pm 0.555$ & $0.471 \pm 0.126$ & $0.191 \pm 0.033$ & 2.8253 & 8.1227 & 8.4394 \\
\hline & WIL & $20.380 \pm 4.013$ & $-12.056 \pm 4.696$ & $-1.373 \pm 0.328$ & 2.8486 & 8.2569 & 8.5788 \\
\hline & GS & $17.117 \pm 1.296$ & $-9.235 \pm 1.613$ & $6.996 \pm 1.579$ & 2.8294 & 8.1465 & 8.4642 \\
\hline \multicolumn{8}{|c|}{$11.247 \pm 0.602$} \\
\hline & WOD & $9.335 \pm 0.440$ & $0.556 \pm 0.103$ & $0.247 \pm 0.027$ & 2.8626 & 8.2824 & 8.5045 \\
\hline & WIL & $25.498 \pm 3.097$ & $-17.740 \pm 3.662$ & $-1.830 \pm 0.251$ & 2.8912 & 8.4482 & 8.6747 \\
\hline & GS & $19.217 \pm 1.000$ & $-11.801 \pm 1.250$ & $9.314 \pm 1.231$ & 2.8636 & 8.2879 & 8.5102 \\
\hline & CLD & $12.187 \pm 0.556$ & $0.875 \pm 0.081$ & $1.095 \pm 0.151$ & 2.8642 & 8.2910 & 8.5134 \\
\hline \multicolumn{8}{|c|}{$5^{\text {th }}$} \\
\hline & WOD & $10.030 \pm 0.451$ & $0.650 \pm 0.114$ & $0.296 \pm 0.033$ & 2.4562 & 6.1150 & 6.3121 \\
\hline & WIL & $23.668 \pm 3.517$ & $-15.267 \pm 4.045$ & $-1.802 \pm 0.297$ & 2.5007 & 6.3384 & 6.5427 \\
\hline & GS & $18.943 \pm 1.120$ & $-12.196 \pm 1.367$ & $8.942 \pm 1.301$ & 2.4659 & 6.1633 & 6.3620 \\
\hline & CLD & $11.966 \pm 0.553$ & $0.987 \pm 0.086$ & $1.224 \pm 0.179$ & 2.4657 & 6.1622 & 6.3608 \\
\hline \multicolumn{8}{|c|}{$6^{\text {th }}$} \\
\hline & WOD & $10.638 \pm 0.510$ & $0.453 \pm 0.144$ & $0.223 \pm 0.033$ & 2.7020 & 7.4247 & 7.7062 \\
\hline & WIL & $18.965 \pm 4.067$ & $-9.254 \pm 4.673$ & $-1.351 \pm 0.342$ & 2.7472 & 7.6460 & 7.9359 \\
\hline & GS & $18.568 \pm 1.237$ & $-9.928 \pm 1.580$ & $6.923 \pm 1.494$ & 2.7121 & 7.4790 & 7.7635 \\
\hline & CLD & $11.711 \pm 0.532$ & $0.850 \pm 0.008$ & $1.569 \pm 0.273$ & 2.7162 & 7.4472 & 7.7296 \\
\hline \multicolumn{8}{|c|}{$7^{\text {th }}$} \\
\hline & WOD & $10.703 \pm 0.282$ & $0.344 \pm 0.068$ & $0.187 \pm 0.021$ & 2.3949 & 5.7741 & 5.8821 \\
\hline & WIL & $18.775 \pm 2.696$ & $-9.096 \pm 3.046$ & $-1.306 \pm 0.237$ & 2.4037 & 5.8166 & 5.9253 \\
\hline & GS & $17.699 \pm 0.878$ & $-8.735 \pm 1.027$ & $5.702 \pm 0.936$ & 2.3956 & 5.7772 & 5.8852 \\
\hline & CLD & $11.222 \pm 0.304$ & $0.787 \pm 0.056$ & $1.984 \pm 0.276$ & 2.3980 & 5.7889 & 5.8971 \\
\hline
\end{tabular}

${ }^{1}$ Model; WOD: Wood (1967); WIL: Wilmink(1987); GS: Guo and Swalve(1995) and CLD: Cobby and Le Du (1978).

${ }^{2}$ Regression parameter estimates where: $a$ is the initial milk yield after calving; $b$ is the ascending slope parameter up to peak yield;

$c$ is descending slope parameter after peak yield and (a's, b's and c's) per lactation were significant $(\mathrm{P}<0.05)$.

${ }^{3}$ Criteria; RSD: Residual Standard Deviation, AIC: Akaike Information Criterion and SBC: Schwarz Bayesian Criterion. 
Table 2. Estimated regression parameters and their standard errors and criteria of expected curves for daily fat yield

\begin{tabular}{|c|c|c|c|c|c|c|}
\hline \multirow{2}{*}{$\begin{array}{c}\text { Lactation } \\
\text { number / } \\
\text { model }^{1}\end{array}$} & \multicolumn{3}{|c|}{ Regression parameters estimates ${ }^{2}$} & \multicolumn{3}{|c|}{ Criteria $^{3}$} \\
\hline & $\mathbf{a} \pm \mathbf{S E}$ & $\mathbf{b} \pm \mathbf{S E}$ & $\mathrm{c} \pm \mathrm{SE}$ & RSD & AIC & SBC \\
\hline \multicolumn{7}{|l|}{$1^{\text {st }}$} \\
\hline WOD & $0.455 \pm 0.028$ & $0.147 \pm 0.122$ & $0.069 \pm 0.030$ & 0.1850 & 0.0340 & 0.0360 \\
\hline WIL & $0.603 \pm 0.229$ & $-0.157 \pm 0.269$ & $0.024 \pm 0.018$ & 0.1859 & 0.0350 & 0.0361 \\
\hline GS & $0.628 \pm 0.072$ & $-0.208 \pm 0.092$ & $0.151 \pm 0.091$ & 0.1854 & 0.0348 & 0.0359 \\
\hline CLD & $0.488 \pm 0.025$ & $0.016 \pm 0.004$ & $2.010 \pm 0.642$ & 0.1853 & 0.0348 & 0.0359 \\
\hline \multicolumn{7}{|l|}{$2^{\text {nd }}$} \\
\hline WOD & $0.492 \pm 0.032$ & $0.487 \pm 0.142$ & $0.171 \pm 0.038$ & 0.2001 & 0.0401 & 0.0420 \\
\hline WIL & $1.301 \pm .0268$ & $-0.884 \pm 0.310$ & $-0.083 \pm 0.022$ & 0.2021 & 0.0415 & 0.0430 \\
\hline GS & $0.930 \pm 0.088$ & $-0.516 \pm 0.107$ & $0.423 \pm 0.103$ & 0.2012 & 0.0411 & 0.0426 \\
\hline CLD & $0.630 \pm 0.045$ & $0.035 \pm 0.006$ & $1.178 \pm 0.257$ & 0.2009 & 0.0410 & 0.0425 \\
\hline \multicolumn{7}{|l|}{$3^{\text {rd }}$} \\
\hline WOD & $0.535 \pm 0.039$ & $0.508 \pm 0.152$ & $0.182 \pm 0.039$ & 0.2080 & 0.0440 & 0.0451 \\
\hline WIL & $1.461 \pm 0.294$ & $-1.009 \pm 0.344$ & $-0.096 \pm 0.024$ & 0.2092 & 0.0445 & 0.0463 \\
\hline GS & $1.031 \pm 0.095$ & $-0.581 \pm 0.119$ & $0.473 \pm 0.116$ & 0.2087 & 0.0443 & 0.0460 \\
\hline CLD & $0.702 \pm 0.052$ & $0.041 \pm 0.007$ & $1.104 \pm 0.257$ & 0.2086 & 0.0443 & 0.0460 \\
\hline \multicolumn{7}{|l|}{$4^{\text {th }}$} \\
\hline WOD & $0.570 \pm 0.032$ & $0.656 \pm 0.122$ & $0.242 \pm 0.032$ & 0.2130 & 0.0451 & 0.0470 \\
\hline WIL & $1.569 \pm 0.231$ & $-1.093 \pm 0.270$ & $-0.121 \pm 0.022$ & 0.2158 & 0.0471 & 0.0483 \\
\hline GS & $1.184 \pm 0.074$ & $-0.734 \pm 0.093$ & $0.588 \pm 0.091$ & 0.2138 & 0.0462 & 0.0474 \\
\hline CLD & $0.751 \pm 0.040$ & $0.052 \pm 0.005$ & $1.087 \pm 0.173$ & 0.2136 & 0.0461 & 0.0474 \\
\hline \multicolumn{7}{|l|}{$5^{\text {th }}$} \\
\hline WOD & $0.598 \pm 0.033$ & $0.805 \pm 0.140$ & $0.321 \pm 0.040$ & 0.1810 & 0.0332 & 0.0334 \\
\hline WIL & $1.508 \pm 0.259$ & $-1.006 \pm 0.298$ & $-0.113 \pm 0.018$ & 0.1850 & 0.0347 & 0.0358 \\
\hline GS & $1.171 \pm 0.082$ & $-0.819 \pm 0.101$ & $0.524 \pm 0.069$ & 0.1821 & 0.0336 & 0.0347 \\
\hline CLD & $0.706 \pm 0.042$ & $0.063 \pm 0.006$ & $1.196 \pm 0.169$ & 0.1817 & 0.0335 & 0.0345 \\
\hline \multicolumn{7}{|l|}{$6^{\text {th }}$} \\
\hline WOD & $0.625 \pm 0.038$ & $0.400 \pm 0.144$ & $0.197 \pm 0.042$ & 0.2084 & 0.0440 & 0.0460 \\
\hline WIL & $0.936 \pm 0.313$ & $-0.361 \pm 0.360$ & $-0.063 \pm 0.026$ & 0.2114 & 0.0454 & 0.0472 \\
\hline GS & $1.049 \pm 0.102$ & $-0.531 \pm 0.122$ & $0.367 \pm 0.115$ & 0.2090 & 0.0448 & 0.0465 \\
\hline CLD & $0.681 \pm 0.038$ & $0.046 \pm 0.006$ & $1.640 \pm 0.361$ & 0.2093 & 0.0445 & 0.0462 \\
\hline \multicolumn{7}{|l|}{$7^{\text {th }}$} \\
\hline WOD & $0.637 \pm 0.021$ & $0.354 \pm 0.087$ & $0.184 \pm 0.026$ & 0.1850 & 0.0340 & 0.0350 \\
\hline WIL & $0.916 \pm 0.209$ & $-0.351 \pm 0.236$ & $-0.056 \pm 0.018$ & 0.1869 & 0.0351 & 0.0358 \\
\hline GS & $1.007 \pm 0.068$ & $-0.522 \pm 0.079$ & $0.348 \pm 0.072$ & 0.1861 & 0.0349 & 0.0355 \\
\hline CLD & $0.677 \pm 0.023$ & $0.036 \pm 0.004$ & $1.860 \pm 0.297$ & 0.1859 & 0.0348 & 0.0355 \\
\hline
\end{tabular}

${ }^{1}$ Model; WOD: Wood (1967); WIL: Wilmink(1987); GS: Guo and Swalve(1995) and CLD: Cobby and Le Du (1978).

${ }^{2}$ Regression parameter estimates where: $a$ is the initial milk yield after calving; $b$ is the ascending slope parameter up to peak yield; $c$ is descending slope parameter after peak yield and (a's, b's and c's) per lactation were significant $(\mathrm{P}<0.05)$.

${ }^{3}$ Criteria; RSD: Residual Standard Deviation, AIC: Akaike Information Criterion and SBC: Schwarz Bayesian Criterion.

As for WOD model, CLD had similar pattern for parameter "a" in the $1^{\text {st }}$ lactation. It increased up to the $4^{\text {th }}$ lactation and declined in subsequent ones (Tables 1 to 3 ). On the contrary, WIL and GS models had the highest average initial daily yields "a" across lactations for daily yield traits (Tables 1 to 3 ). The average initial daily yields "a" tended to increase rapidly until the $4^{\text {th }}$ and $5^{\text {th }}$ lactations, respectively followed by a gradual decline till the $7^{\text {th }}$ lactation. Similar trend was recorded in Egyptian buffalo cows by Aziz et al. (2006) and Abdel-Salam et al. (2011).

For daily yield traits, as shown in Tables (1 to 3) the ascending slope parameter of " $b$ " of WOD and CLD equations had a similar pattern. For MY among lactations, rate incline after calving up to peak (slope parameter " $b$ ") ranged from 0.211 to $0.650,0.341$ to
0.987, respectively. The corresponding values for FY varied between 0.147 and $0.656,0.016$ and 0.052 , respectively, while ranged from 0.205 to 0.602 and 0.010 to 0.033 , for PY respectively. The similar pattern of slope parameter " $b$ " for daily yields with parity order were reported by Silvestre et al. (2009), Cankaya et al. (2011) and Jingar et al. (2014) for dairy cows. According to the results of WIL and the GS equations, rate of incline after calving up to peak (slope parameter " $b$ ") ranged from -4.035 to -17.740 and -4.338 to- 12.196 , for MY and -0.157 to -1.093 and -0.208 to -0.819 for FY and -0.163 to -0.591 and -0.148 to -0.414 , for PY, respectively (Tables 1 to 3 ) in the first 7 lactations. These results are consistent with those reported by Cankaya et al. (2011). 
Egyptian J. Anim. Prod. (2016)

Table 3. Estimated regression parameters and their standard errors and criteria of expected curves for daily protein yield

\begin{tabular}{|c|c|c|c|c|c|c|}
\hline \multirow{2}{*}{$\begin{array}{c}\text { Lactation } \\
\text { number / } \\
\text { model }^{1}\end{array}$} & \multicolumn{3}{|c|}{ Regression parameter estimates $^{2}$} & \multicolumn{3}{|c|}{ Criteria $^{3}$} \\
\hline & $\mathbf{a} \pm \mathbf{S E}$ & $\mathbf{b} \pm \mathbf{S E}$ & $\mathbf{c} \pm \mathbf{S E}$ & RSD & AIC & SBC \\
\hline \multicolumn{7}{|l|}{$1^{\text {st }}$} \\
\hline WOD & $0.266 \pm 0.016$ & $0.205 \pm 0.121$ & $0.082 \pm 0.029$ & 0.1060 & 0.0105 & 0.0111 \\
\hline WIL & $0.419 \pm 0.132$ & $-0.163 \pm 0.155$ & $-0.019 \pm 0.010$ & 0.1072 & 0.0116 & 0.0120 \\
\hline GS & $0.390 \pm 0.041$ & $-0.148 \pm 0.053$ & $0.115 \pm 0.052$ & 0.1069 & 0.0116 & 0.0120 \\
\hline CLD & $0.295 \pm 0.016$ & $0.010 \pm 0.002$ & $1.782 \pm 0.511$ & 0.1068 & 0.0116 & 0.0120 \\
\hline \multicolumn{7}{|l|}{$2^{\text {nd }}$} \\
\hline WOD & $0.304 \pm 0.018$ & $0.488 \pm 0.135$ & $0.190 \pm 0.037$ & 0.1090 & 0.0120 & 0.0120 \\
\hline WIL & $0.668 \pm 0.147$ & $-0.399 \pm 0.170$ & $-0.043 \pm 0.012$ & 0.1112 & 0.0125 & 0.0130 \\
\hline GS & $0.562 \pm 0.048$ & $-0.310 \pm 0.058$ & $0.242 \pm 0.056$ & 0.1100 & 0.0123 & 0.0127 \\
\hline CLD & $0.368 \pm 0.021$ & $0.022 \pm 0.003$ & $1.305 \pm 0.253$ & 0.1098 & 0.0122 & 0.0127 \\
\hline \multicolumn{7}{|l|}{$3^{\text {rd }}$} \\
\hline WOD & $0.349 \pm 0.021$ & $0.457 \pm 0.131$ & $0.185 \pm 0.035$ & 0.1082 & 0.0111 & 0.0120 \\
\hline WIL & $0.688 \pm 0.153$ & $-0.469 \pm 0.180$ & $-0.058 \pm 0.012$ & 0.1095 & 0.0122 & 0.0127 \\
\hline GS & $0.567 \pm 0.050$ & $-0.366 \pm 0.062$ & $0.283 \pm 0.061$ & 0.1095 & 0.0122 & 0.0127 \\
\hline CLD & $0.379 \pm 0.020$ & $0.022 \pm 0.003$ & $1.283 \pm 0.536$ & 0.1090 & 0.0121 & 0.0126 \\
\hline \multicolumn{7}{|l|}{$4^{\text {th }}$} \\
\hline WOD & $0.330 \pm 0.017$ & $0.481 \pm 0.116$ & $0.222 \pm 0.030$ & 0.1160 & 0.0131 & 0.0135 \\
\hline WIL & $0.867 \pm 0.125$ & $-0.591 \pm 0.146$ & $-0.061 \pm 0.010$ & 0.1172 & 0.0139 & 0.0142 \\
\hline GS & $0.652 \pm 0.040$ & $-0.383 \pm 0.050$ & $0.300 \pm 0.050$ & 0.1167 & 0.0138 & 0.0141 \\
\hline CLD & $0.419 \pm 0.002$ & $0.028 \pm 0.003$ & $1.163 \pm 0.201$ & 0.1168 & 0.0138 & 0.0142 \\
\hline \multicolumn{7}{|l|}{$5^{\text {th }}$} \\
\hline WOD & $0.341 \pm 0.016$ & $0.602 \pm 0.115$ & $0.285 \pm 0.036$ & 0.0923 & 0.0080 & 0.0083 \\
\hline WIL & $0.791 \pm 0.132$ & $-0.501 \pm 0.152$ & $-0.051 \pm 0.111$ & 0.0941 & 0.0090 & 0.0093 \\
\hline GS & $0.636 \pm 0.042$ & $-0.414 \pm 0.051$ & $0.285 \pm 0.049$ & 0.0929 & 0.0087 & 0.0090 \\
\hline CLD & $0.409 \pm 0.020$ & $0.033 \pm 0.003$ & $1.229 \pm 0.190$ & 0.0927 & 0.0087 & 0.0090 \\
\hline \multicolumn{7}{|l|}{$6^{\text {th }}$} \\
\hline WOD & $0.361 \pm 0.019$ & $0.440 \pm 0.127$ & $0.212 \pm 0.037$ & 0.1020 & 0.0100 & 0.0103 \\
\hline WIL & $0.657 \pm 0.153$ & $-0.340 \pm 0.176$ & $-0.047 \pm 0.012$ & 0.1037 & 0.0109 & 0.0114 \\
\hline GS & $0.624 \pm 0.050$ & $-0.327 \pm 0.060$ & $0.227 \pm 0.056$ & 0.1032 & 0.0108 & 0.0112 \\
\hline CLD & $0.395 \pm 0.020$ & $0.028 \pm 0.003$ & $1.639 \pm 0.353$ & 0.1031 & 0.0108 & 0.0112 \\
\hline \multicolumn{7}{|l|}{$7^{\text {th }}$} \\
\hline WOD & $0.381 \pm 0.011$ & $0.279 \pm 0.074$ & $0.173 \pm 0.023$ & 0.0930 & 0.0082 & 0.0083 \\
\hline WIL & $0.602 \pm 0.104$ & $-0.261 \pm 0.118$ & $-0.044 \pm 0.009$ & 0.0934 & 0.0088 & 0.0089 \\
\hline GS & $0.605 \pm 0.034$ & $-0.280 \pm 0.040$ & $0.171 \pm 0.036$ & 0.0933 & 0.0088 & 0.0089 \\
\hline CLD & $0.386 \pm 0.010$ & $0.027 \pm 0.002$ & $2.350 \pm 0.429$ & 0.0932 & 0.0087 & 0.0089 \\
\hline
\end{tabular}

${ }^{1}$ Model; WOD: Wood (1967); WIL: Wilmink(1987); GS: Guo and Swalve(1995) and CLD: Cobby and Le Du (1978).

${ }^{2}$ Regression parameter estimates where: $a$ is the initial milk yield after calving; $b$ is the ascending slope parameter up to peak yield; $c$ is descending slope parameter after peak yield and (a's, b's and c's) per lactation were significant $(\mathrm{P}<0.05)$.

${ }^{3}$ Criteria; RSD: Residual Standard Deviation, AIC: Akaike Information Criterion and SBC: Schwarz Bayesian Criterion.

Table 4. Peak yield (PY, kg), time at peak yield (TPY, wk) and persistency (P, \%) for Wood function predicted curves of daily milk yield traits (MY, FY, and PY) in the first seven lactations

\begin{tabular}{lllllllllll}
\hline \multirow{2}{*}{ Lactation } & \multicolumn{3}{c}{$\mathbf{P Y}, \mathbf{k g}$} & \multicolumn{3}{c}{ TPY, wk } & \multicolumn{3}{c}{$\mathbf{P ,} \%$} \\
\cline { 2 - 10 } & \multicolumn{2}{c}{$\mathbf{M Y}$} & $\mathbf{F Y}$ & $\mathbf{P Y}$ & $\mathbf{M Y}$ & $\mathbf{F Y}$ & $\mathbf{P Y}$ & $\mathbf{M Y}$ & $\mathbf{F Y}$ & $\mathbf{P Y}$ \\
\hline $1^{\text {st }}$ & 6.50 & 0.395 & 0.230 & 6.76 & 6.27 & 7.86 & 65.90 & 72.00 & 70.41 \\
$2^{\text {nd }}$ & 7.01 & 0.437 & 0.249 & 8.23 & 9.35 & 8.13 & 55.19 & 58.79 & 54.14 \\
$3^{\text {rd }}$ & 7.38 & 0.467 & 0.261 & 7.71 & 9.11 & 7.19 & 53.06 & 57.08 & 53.76 \\
$4^{\text {th }}$ & 7.22 & 0.452 & 0.258 & 6.79 & 8.76 & 6.43 & 45.28 & 50.49 & 46.87 \\
$5^{\text {th }}$ & 6.92 & 0.430 & 0.239 & 6.55 & 7.87 & 6.20 & 40.26 & 41.53 & 40.33 \\
$6^{\text {th }}$ & 7.31 & 0.440 & 0.249 & 5.85 & 5.84 & 6.04 & 45.41 & 48.23 & 47.01 \\
$7^{\text {th }}$ & 4.59 & 0.462 & 0.263 & 5.03 & 5.39 & 4.05 & 47.60 & 48.76 & 47.32 \\
\hline
\end{tabular}


According to results of Macciotta (2005) revealed that the absolute value of " $b$ " parameter and the "c" parameter of WIL are mainly related to variation in the first part and the rate of decline in the second part of lactation, respectively; control the magnitude of the curvature of the lactation pattern.

Results in Tables (1 to 3) show that the descending slope parameter " $c$ " of WOD equation was lower 0.094, 0.069 and 0.082, for MY, FY and PY in the $1^{\text {st }}$ lactation and higher $0.296,0.321$ and 0.285 in the fifth lactation, respectively. Different pattern was reported for Egyptian buffalo by Aziz et al. (2006). They found that all lactations had a constant $\left(1^{\text {st }}\right.$ through $\left.10^{\text {th }}\right)$ descending slope parameter " $c$ " after peak for Wood equation.

According to the results of GS and CLD equations, rate of decline after peak yield were 3.234 to 9.314 and 1.095 to 1.984 for MY and 0.151 to 0.588 and 1.087 to 2.010 for FY and 0.115 to 0.300 and 1.163 to 2.350 , for PY, respectively during different lactations. The corresponding values of WIL equation varied from -0.558 to $-1.830,-0.024$ to -0.121 and -0.019 to -0.061 for MY, FY and PY, respectively.

The pattern of descending slope parameter " $c$ " observed in this study was in agreement with the findings of Silvestre et al, (2009) and Jingar et al. (2014). However, Solkner and Fuchs (1987) suggested that the high persistency was associated with a slow rate of decline in milk yield after peak production, low persistency was associated with a rapid rate of decline in milk yield due to less feed intake.

\section{Model selection criteria:}

Estimates of criteria for evaluating different models were shown in Tables (1,2 and 3). Lowest values of Residual Standard Deviation (RSD), Akaike Information Criterion (AIC) and Schwarz Bayesian Criterion (SBC) indicated that the model used was appropriately fitting the data as reported by Akaike (1974); Schwarz (1978); Neter et al. (1985);Grossman and Koops (1988) and Littell et al. (1998). Compared with the WIL, the three other models (GS, CLD and WOD) showed lower values of RSD, AIC and SBC criteria over the first 7lactations. For milk yield among lactations, RSD, AIC and SBC values of different models (Table 1) ranged from 2.3949 to $2.8912 \mathrm{~kg}, 5.7741$ to 8.4482 $\mathrm{kg}$, and 5.8821 to $8.6747 \mathrm{~kg}$, respectively. On the other hand, Table (2) showed that the corresponding values varied between 0.1810 and $0.2158 \mathrm{~kg}, 0.0332$ and $0.0471 \mathrm{~kg}$ and 0.0434 and $0.0483 \mathrm{~kg}$, for daily fat yield, respectively. The corresponding values for daily protein yield of different models ranged from 0.0923 to $0.1172 \mathrm{~kg}, 0.0080$ to $0.0139 \mathrm{~kg}$, and 0.0083 to $0.0142 \mathrm{~kg}$, respectively (Table 3 ). Moreover, there are considerable differences among models for the regression parameter values.

Based on the previous mentioned criteria, Wood's model was more flexibility than the other models to explore lactation curve pattern for expected daily milk yield traits. These results were in agreement with those reports of Samak et al. (1988), Mansour et al. (1993), Aziz et al. (2006) and AbdelSalam et al. (2011) for Egyptian buffalo. They mentioned that Wood's function seemed to be suitable for Egyptian lactation data and might be used for predicting the whole lactation yield from part lactation data.

For other populations of buffaloes, Kumar and Bhat (1979) found that the best fit for average milk lactation curve was shown by the Gamma type function data from the $1^{\text {st }}$ to the $6^{\text {th }}$ lactations. Catillo et al. (2002) revealed that Wood's function had goodness of fit for lactation curve of milk yield traits. The variables related to lactation curve pattern, in terms of peak yield $(\mathrm{kg})$, time at peak daily yield(wk) and persistency (\%) for predicted lactation curve by Wood function were shown in Table (4) for MY, FY and PY in the first 7 lactations. Considering values obtained by the WOD model, the expected daily yield at peak $(\mathrm{kg})$, time at peak daily yield (wk) and persistency (\%) ranged from 4.59 to $7.38 \mathrm{~kg}, 5.03$ to to $8.23 \mathrm{wk}$ and 40.62 to $65.90 \%$, respectively for MY. On the other hand, the corresponding values of FY (Table 4) varied between 0.395 and $0.467 \mathrm{~kg}$, 5.39 and $9.35 \mathrm{wk}$, and 41.58 and $72.00 \%$, respectively, while ranged between 0.230 and 0.263 $\mathrm{kg}, 4.05$ and $8.13 \mathrm{wk}$, and 40.33 and $70.41 \%$, respectively for $\mathrm{PY}$.

Moreover, higher persistency over the 7 lactations for MY, FY and PY was observed in the $1^{\text {st }}$ lactation (65.90, 72.00 and $70.41 \%$, respectively) which declined till the $5^{\text {th }}$ lactation and then tended to be almost constant till the $7^{\text {th }}$ one $(47.60,48.76$ and $47.32 \%$, respectively (Table 4). If persistency is defined as the extent to which peak yield is maintained (Grossman et al., 1999), lactation curves for daily milk yield traits for the $1^{\text {st }}$ lactation buffalo cows peaked lower and were more persistent than for multiparous animals. Similar pattern was reported by El-Bramony et al. (2004) for Egyptian and Catillo et al. (2002) on Italian buffalo cows.

As expected, the lower initial yield, peak milk yield, and greater persistency in the first parity than the subsequent parities could be due to increase growth rates of heifers and the development of mammary gland secretory tissue (Sejrsen et al., 1982 and Stanton et al., 1992). They stated that the decline in persistency with lactation order advanced is attributed to the fact older animals start their lactation at a higher level and had a rapid rate of decline in milk yield due to regression of alveolar cells with advancement in age.

\section{CONCLUSION}

In a comparison with the WIL, the three models (GS, CLD, and WOD) have the low values with RSD, AIC and SBC criteria in the first seven lactations. Based on previous mentioned criteria, Wood's equation showed more flexibility than other models to explore lactation curve pattern for daily milk yield traits. Further genetic investigation, should 
be considered to identify genetic pattern of milk yield traits using mathematical models.

\section{ACKNOWLEDGMENT}

The authors would like to thank for Dr. Eldho Varghese, Scientist Indian Agricultural Statistics Research Institute for his constructive advice in this study.

\section{REFERENCES}

Abdel-Salam, S.A.M., W. Mekkawy, Y.M. Hafez, A.A. Zaki, S. Abou Bakr, 2011. Fitting lactation curve of Egyptian buffalo using three different models. Egyptian J. Anim. Prod. 48: 119-133.

Akaike, H., 1974. A new look at the statistical model identification. IEEE Trans. on Auto. Control, 19:716-723.

Aziz, M.A, N.A. Shalaby, O. M. El-Shafie, A. T. Mahdy and A. Nishida, 2006. Comparison between the shapes of lactation curve of Egyptian buffalo milk yield estimated by the incomplete gamma function and a new model. Livestock Research for Rural Development 18:1-10.

Badran, A. E., A. El-Barbary, A.E. Mahdy and G. M. Assar, 2002. Genetic and non- genetic factors affecting the lifetime production traits in Egyptian buffaloes. Buffalo J. 2:235-241.

Cankaya, S., Unalan, A and E. Soydan, 2011. Selection of a mathematical model to describe the lactation curves of Jersey cattle. Archiv Tierzucht 54: 27-35.

Catillo, G., N. P. P. Macciotta, A. Carretta and A. Cappio-Borlino, 2002. Effects of age and calving season on lactation curves of milk production traits in Italian water Buffaloes. J. Dairy Sci., 85:1298-1306.

Cerón-Muñoz, M. H. Tonhati, J. Duarte, J. Oliveira, M. Muñoz-Berrocal, and H. Jurado-Gámez. 2002. Factors affecting somatic cell counts and their relations with milk and milk constituent yield in Buffaloes. J. Dairy Sci., 85: 2885-2889.

Cobby, J.M. and Y.L.P. Le Du, 1978. On fitting curves to lactation data. Anim. Prod. 26: 127-133.

Dijkhuizen, A.A., J. A. Renkema, and J. Stelwagen, 1985. Economic aspects of reproductive failure in dairy cattle. II. The decisión to replace animals. Prev. Vet. Med. 3:265-276.

El-Bramony, Manal M., 2011. Factors affecting testday milk yield traits and somatic cell count in Egyptian buffalo. Egypt. J. of Appl. Sci., 26: 5567.

El-Bramony, Manal M., A. A. Nigm, Kawthar A. Mourad and U. M. El-Saied, 2004. Factors Affecting Somatic Cell Counts and their Relations with Milk Yield in Egyptian Buffalo. 12th Scientific Conference, Egyptian Society of Animal Production. Mansoura University, Egypt, November 29-December 3, 2004. Egyptian J. Anim. Prod. 41 (Suppl. Issue): 61-71.
Grossman M. and W.J. Koops, 1988. Multiphasic analysis of lactation curves in dairy cattle. J. Dairy Sci. 71, 1598-1608.

Grossman, M., S.M. Hartz and W.J. Koops, 1999. Persistency of lactation yield: A novel approach. J. Dairy Sci. 82:2192-2197.

Guo, Z. and H.H. Swalve, 1995. Modelling of the lactation curve as a sub-model in the evaluation of test day records. Int. Bull Meeting, Pruhonice, Prague, Open Session Programme, 1-4.

Jingar, S., R., K. Mehla, M. Singh, and A. K. Roy, 2014. Lactation curve pattern and prediction of milk production performance in crossbred cows. J. Vet. Med.

Kumar, R. and P.N. Bhat, 1979. Lactation curve in Indian buffaloes. Indian j. dairy Sci. 32:156-160.

Littell, R. C., P. R. Henry, and C. B. Ammermann. 1998. Statistical analysis of repeated measures data using SAS procedures. J. Anim. Sci. 76:1216-1231.

Macciotta, N. D. Vicario and A. Cappio-Borlino, 2005. Detection of different shapes of lactation curve for milk yield in dairy cattle by empirical mathematical models. J. Dairy Sci. 88:1178-1191.

Mansour, H., Soliman, I. A. and Abd El-Haafiz, G. A. 1993. Factors affecting lactation curve of buffalo in upper Egypt. Proceeding of the international Symp. on prospects of buffalo production in the Mediterranean and middle East. Cairo, Egypt Nov., 9-12 1992. EAAP publications, 62:234-237.

Neter J., Wasserman W. and M.H. Kutner, 1985. Applied linear Statistical. Homewood: Irwin, USA.

Olds, D., T., Cooper and F.A. Thrift, 1979. Effect of days open on econemic Aspects of current lactation. J. Dairy Sci. 88:1178-1191.

Olori V.E., Brotherstone S., Hill W.G. and B.J.Mc. Guirk, 1999. Fit of standard models of the lactation curve to weekly records of milk production of cows in a single herd. Livest. Prod. Sci. 58, 55-63.

Ptak, E. and Schaeffer, L. R. 1993. Use of test day yields for genetic evaluation of dairy sires and cows. Livest. Prod. Sci. 34:23-34.

Samak, M. A., G. A. Hassan, A. Hassan, and N. Yassen. 1988. The lactation curve and performance of the Egyptian buffalo. Alex. Sci. Exch. 9:83-97.

SAS (2002) STAT. Procedure Guide, Version 9.0 SAS Inst., Inc., Cary, NC. USA.

Sejrsen, K., J.T. Huber, H.A. Tucker and R.M. Akers, 1982. Influence of nutrition of mammary development in pre- and postpubertal heifers. J. Dairy Sci., 65:793-800.

Schwarz, G., 1978. Estimating the dimension of a model. Annals of statistics, 6:461-464. (Cited by Littell et al., 1998).

Silvestre, A.M., A.M. Martins, V.A. Santos, M.M. Ginja and J.A. Colaço, 2009. Lactation curves for milk, fat and protein in dairy cows: A full approach. Livest. Prod. Sci. 122: 308-313. 
Solkner, J. and W. Fuchs, 1987. A comparison of different measures of persistency with special respect to variation of test-day milk yields, Livest. Prod. Sci., 16: 305-319.

Stanton, T. L., L. R. Jones, R. W. Everett and S. D. Kachman, 1992. Estimating milk, fat, and protein lactation curves. J. Dairy Sci., 80:1691-1700.

Swalve, H. H. 1995. The effect of test day models on the estimation of genetic parameters and breeding values for dairy yield traits. J. Dairy Sci. 78:929938.

Tonhati, H., M.F.C., Muñoz, J. A. Oliveira, A.L.F. Lima and L.G. Albuquerque, 2008. Test-day milk yield as a selection criterion for dairy buffaloes (Bubalus bubalis Artiodactyla, Bovidae). Genet. Mol. Biol 31:674-679.

Vargas, B., W. J. Koops, M. Herrero and J.A.M. Van Arendonk, 2000. Modeling extended lactations of dairy cows. J. Dairy Sci. 83:1371-1380.

Wilmink J.B.M. 1987. Adjustment of test day milk, fat and protein yield for age, season and stage of lactation. Livest. Prod. Sci. 16: 335-348.

Wood, P. D. P., 1967. Algebraic model of the lactation curve in cattle. Nature, (Lond.) on 216:164-165. (Cited by Catillo, et al., 2002).

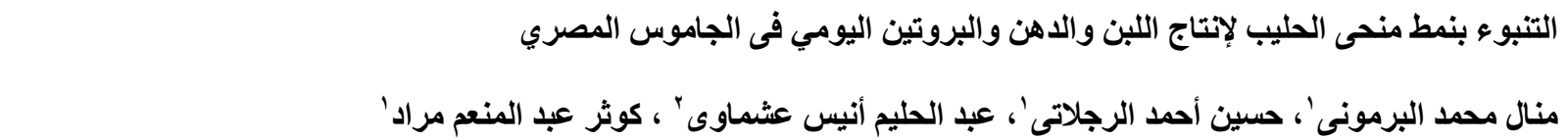

ا ـ معهد بحوث الإنتاج الحيواني، وزارة الزراعة واستصلاح الأراضي، الدقى، جيزه، مصر، بـ قـسم الإنتاج الحيواني، كلية

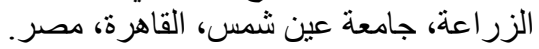

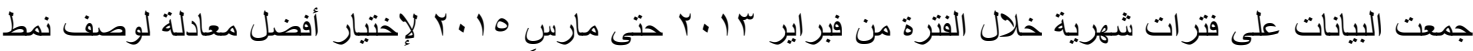

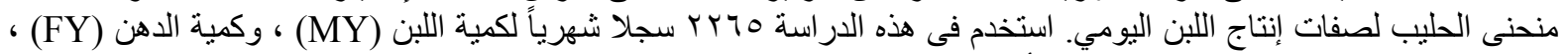

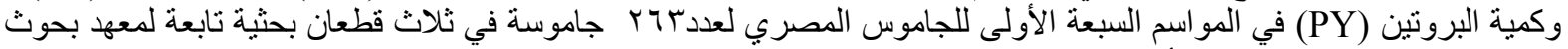

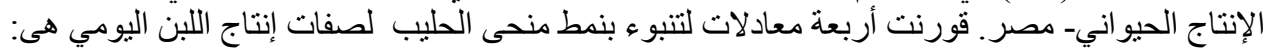

ـ Wood's (WOD), Wilmink's (WIL), Guo and Swalve (GS) and Cobby and Le Du (CLD)

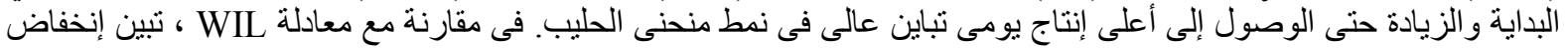
قيم المعايير Residual Standard Deviation (RSD), Akaike Information Criterion (AIC) and Schwarz

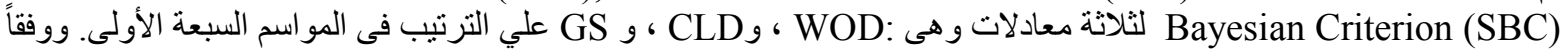

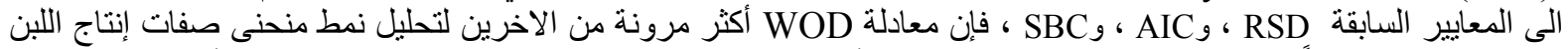

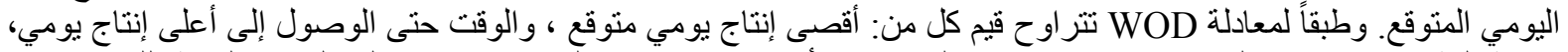

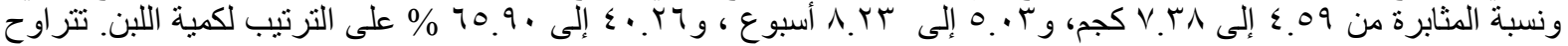

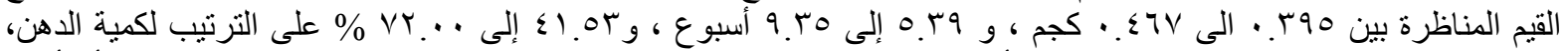

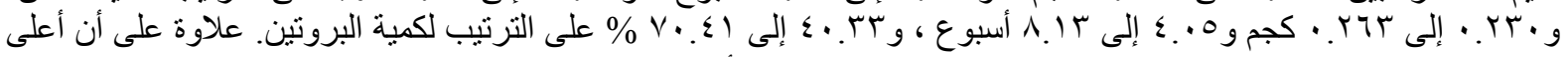

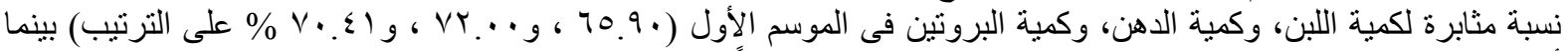

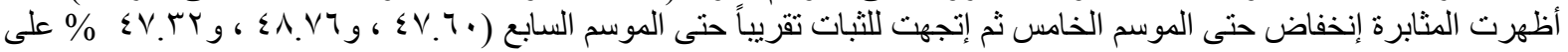

